\title{
EFFECT OF YAM STORAGE TECHNIQUES USAGE ON FARM INCOME IN KWARA STATE, NIGERIA
}

\author{
Falola A. ${ }^{1}$, Salami M. F. ${ }^{1 *}$, Bello A. A. ${ }^{2}$ \& Olaoye T. A. ${ }^{1}$ \\ 1Department of Agricultural Economics and Farm Management, Faculty of Agriculture, P.M.B. \\ 1515, University of Ilorin, Ilorin, Nigeria \\ ${ }^{2}$ National Centre for Agricultural Mechanization, Ilorin, Nigeria \\ *Corresponding Authors Email: markmercy12@gmail.com
}

\begin{abstract}
Yam is an important tuber crop in Nigeria. However, its availability is affected by rate of deterioration arising from poor postharvest handling. Hence, farmers use various techniques to minimize the loss. Therefore, this study examined the effect of the usage of various yam storage techniques on farm income in Kwara State, Nigeria. Data were collected from 180 respondents and analyzed with descriptive statistics, Tobit regression, weight index, and bivariate correlation. Data analysis reveals that yam barn storage technique was ranked first in terms of level of usage by the farmers with the highest average weight index (AWl=2.54) while, open sided shelve was the least $(A W I=0.594)$. However, in terms of level of awareness, the heap on the floor technique was ranked first by the respondents. The Tobit regression analysis indicates that extension service and crop yield had a positive and significant effect on the usage of yam storage techniques, while access to credit had a negative significant effect. The bivariate correlation reveals that; there is a positive significance between usage intensity and farm income of the farmers. It is therefore recommended that extension agents should actively disseminate information on improved storage techniques to yam farmers in the study area as well as the need to use such techniques.
\end{abstract}

Keywords: storage technique, postharvest loss, yam barn, usage, awareness 


\section{INTRODUCTION}

Yam belongs to the genus Dioscorea (Family Dioscoreaceae) and is the second most important tropical root crop in West Africa after cassava (Adisa et. al.,2015).Yams are among the most important staple food crops in the world particularly in the tropical and sub-tropical countries (Okigbo \& Ogbonnaya, 2006). In fact, yam plays a central role in the food economy in most West African Countries especially Nigeria. Yam is a major source of energy in the daily diet of many people in Nigeria. Yam contributes more than 200 calories per person per day for more than 150 million people in West Africa (FAO, 2005).

Yam is an annual crop, so for it to be available throughout the year, harvested tubers must be stored for six to eight months before new yams are harvested. The possibility to store fresh yam tubers is decisively influenced by their dormancy which occurs shortly after their physiological maturity (wilting point). During the storage period, a substantial amount of yam is lost. Postharvest food losses are one of the major causes of food insecurity in Africa. According to AMCOST (2006), pre- and post-harvest food crop loss among African countries is estimated at about $10 \%$, which is higher than the global average. Although it has been difficult to quantify post-harvest storage losses, some claim that as much as $20 \%$ of yam tubers may be lost to pest attack in storage (FAO 2005).

Tropical root and tuber crops such as cassava, yam, and cocoyam are important household food security and income generating crops in many African countries (AMCOST 2006), and over 5 million people are said to depend on these crops for food, feeds, and income. Thus, losses associated with these crops limit the potential income of the farmers, threaten food security and exacerbate conditions of poverty among rural households, whose income stream depends on the ability to store excess farm produce for a later date.

To minimize post-harvest losses, improved methods of storage have therefore been developed. However, the poor economic status of most Nigerian farmers has inhibited the adoption and usage of most agricultural technologies (Alimi \& Zango, 2016). It was hoped that farmers' usage of these technologies would lead to reduction in food losses, improved income and enhanced food security (Okoedo-Okojie \& Onemolease , 2009). Nevertheless, the widespread and continued use of traditional storage practices by small-scale farmers despite considerable losses usually associated with these methods need investigation.

Though many studies such as Akangbe et al., (2012); Okoedo-Okojie \& Onemolease (2009), have focused on the yam storage technology, however, none of them has paid specific 
attention to the economic impact of using such yam storage techniques. This study tried to fill the identified research gap. The specific objectives were to: identify yam storage techniques available to the farmers; determine the level of use of yam storage technology by the farmers; determine factors influencing use of the yam storage techniques by the farmers; and determine the effect of the farm storage techniques used on the farmer's income.

\section{METHODOLOGY}

\section{Study Area}

This study was carried out in Kwara State, North Central Nigeria. It covers an estimated land area of 36,825 square $\mathrm{km}$ with a population of about 2.37 million (NPC, 2006). The state was created in 1967 and is made up of 16 Local Government Areas (LGAs). It shares national boundaries with Niger, Oyo, Kogi, and Osun states and international boundaries with the Republic of Benin.

\section{Source of Data}

Primary data were collected through administration of structured questionnaire combined with interview schedule. This is because majority of the farmers cannot fill the questionnaires themselves.

\section{Sampling procedure and Sample size}

The population for the study comprised yam farmers in Kwara State, Nigeria. A multi staged random sampling technique was employed as a sampling procedure for the study. In the first stage, a purposive selection of Asa, Baruten, and Kaiama, L.G.As out of the 16 Local Government Areas was made. This is because yam production is predominant in the selected L.G.As. In the second stage, five (5) villages were randomly selected from each of the L.G.As. Lastly, twelve (12) yam farmers were randomly selected from each village. A total of 180 yam producing farmers were selected for the study.

\section{Analytical Techniques:}

The following analytical techniques were employed for the purpose of this study:

Descriptive statistics:

Descriptive statistics like frequencies, percentages, averages and means were used to describe the socio-economic characteristic of the farmers. The simple descriptive analysis was also used to identify the yam storage techniques available for the respondents. Index ranking: 
Index ranking was used to determine the level of use of yam storage technology by farmers. Responses for this was rated by using a four-point scale with the scoring order of 3, 2, 1 and 0 as often, moderately, seldom, and 'not at all' respectively. A weighted average index (WAI) analysis was then estimated using the formula:

$$
\begin{gathered}
\text { WAI }=\frac{F_{3} W_{3}+F_{2} W_{2}+F_{1} W_{1}+F_{0} W_{0}}{F_{3}+F_{2}+F_{1}+F_{0}} \\
\text { WAI }=\frac{\sum F_{i} W_{i}}{\sum F_{i}}=\frac{W I}{\sum F_{i}} \ldots \ldots \ldots \ldots \ldots
\end{gathered}
$$

Where: $F=$ frequency; $W i=$ weight of each scale; $i=$ individual scale; $W I=$ weighted index (Ndamani and Watanabe, 2016)

Tobit regression model

Tobit regression model was used to determine factors influencing use of the yam storage technology by the farmers.

Tobit model was used to estimate the propensity of farmers to exhibit discontinued usage behaviour. The Tobit model, originally developed by James Tobin in 1958, may be expressed in the following way: $Y^{*}=X_{1} \beta+\varepsilon$

Where:

$\beta=$ is a vector of unknown coefficients,

$X$ is a vector of independent variables,

$\varepsilon=$ is an error term that is assumed to be independently distributed with mean zero and a variance of $\mathrm{s}^{2}$.

$\mathrm{Y}^{*}=$ intensity of the use defined as a/A where $\mathrm{a}$ is the number of the yam storage technique that is used by the yam farmer and $A$ is the total number of techniques available for use.

$\mathrm{X}_{1}=$ distance to market (kilometer)

$X_{2}=$ household size (number of persons in the household)

$X_{3}=$ educational status (years)

$X_{4}=$ membership of an agricultural association

$X_{5}=$ access to credit (naira)

$X_{6}=$ total harvested (tonnes)

$X_{7}=$ extension access ( $D=1$ if yes; 0 , if otherwise)

$X_{8}=$ farm size (hectare) 
$X_{9}=$ farming experience (years)

$\varepsilon=$ is an error term that is assumed to be independently distributed with mean zero

If data for the dependent variable is above the limiting factor, zero, in this case, $Y$ is observed as a continuous variable. If $Y$ is the limiting factor, it is held at zero. This relationship is presented mathematically in the following two equations:

$$
\begin{aligned}
& Y=Y^{*} \text { if } Y^{*}>Y 0 \\
& Y=0 \text { if } Y^{*}<Y 0
\end{aligned}
$$

Where: $Y 0$ is the limiting factor. These two equations represent a censored distribution of the data. The Tobit model can be used to estimate the expected value of $Y i$ as a function of a set of explanatory variables $(X)$ weighted by the probability that $\mathrm{Yi}>0$.

The expected intensity of usage,

$$
E(Y) \text {, is: } E(Y)=X \beta F(z)+\sigma f(z) \text { and } z=X \beta / \sigma
$$

Where: $F(z)$ is the cumulative normal distribution of $z, f(z)$ is the value of the derivative of the normal curve at a given point (unit normal density), $z$ is the Z-score for the area under the normal curve, and $\sigma$ is the standard error of the error term (Oladele \& Kareem 2003). The coefficients for variables in the model, $\beta$, do not represent marginal effects directly, but the sign of the coefficient will give the researcher information as to the direction of the effect.

Correlation model

Correlation was used to determine the effect of usage of yam storage techniques on the farm income

$$
\frac{n \sum x y-\left(\sum x\right)\left(\sum y\right)}{\sqrt{n} \sum x^{2}-\left(\sum x^{2}\right)\left(n \sum y^{2}-\left(\sum y^{2}\right)\right)}
$$

$\mathrm{N}=$ number of pairs of scores

$\sum x y=$ sum of the product of paired scores

$\sum y=$ sum of usage intensity score

$\sum x=$ sum of income score

$\sum x^{2}=$ sum of square of income

$\sum y^{2}=$ sum of square of usage intensity 


\section{RESULTS AND DISCUSSION}

Table 1 Socio-Economic Characteristic of the Respondents

\begin{tabular}{|c|c|c|c|c|}
\hline Variable & Characteristic & Frequency $(\mathrm{N}=180)$ & Percentage & Mean \\
\hline \multirow[t]{2}{*}{ Sex } & Male & 133 & 73.9 & \\
\hline & Female & 47 & 26.1 & \\
\hline \multirow[t]{6}{*}{ Age } & $\leq 30$ & 14 & 7.8 & 48.21 \\
\hline & $31-40$ & 38 & 21.1 & \\
\hline & $41-50$ & 49 & 27.2 & \\
\hline & $51-60$ & 52 & 28.9 & \\
\hline & $61-70$ & 22 & 12.2 & \\
\hline & 71 and above & 5 & 2.8 & \\
\hline \multirow[t]{3}{*}{ Marital status } & Single & 24 & 13.3 & \\
\hline & Married & 120 & 66.7 & \\
\hline & Widowed & 36 & 20 & \\
\hline \multirow{3}{*}{ Household size } & $1-5$ & 73 & 40.6 & 5.92 \\
\hline & $6-10$ & 100 & 55.6 & \\
\hline & 11 and above & 7 & 3.9 & \\
\hline \multirow[t]{4}{*}{ Education level } & No formal & 77 & 42.8 & \\
\hline & Primary education & 45 & 25 & \\
\hline & Secondary education & 41 & 22.8 & \\
\hline & Tertiary education & 17 & 9.4 & \\
\hline \multirow[t]{6}{*}{ Farming experience } & $\leq 10$ & 30 & 16.7 & \\
\hline & $11-20$ & 58 & 32.2 & \\
\hline & $21-30$ & 33 & 18.3 & \\
\hline & $31-40$ & 36 & 20 & \\
\hline & $41-50$ & 16 & 8.9 & \\
\hline & $51-60$ & 7 & 3.9 & 24.99 \\
\hline
\end{tabular}

Source: Field survey, 2016

The result in Table 1 revealed that yam production in the study area is dominated by male $(73.9 \%)$. This is probably because yam production is energy demanding thus female farmers 
prefer to go into the production of other crops. This result is in line with the finding of Suleiman (2014) and Ekunwe and Osewa (2007) who noted that $85 \%$ of yam farmers in kiama Kwara State were males.

The result revealed that $77.2 \%$ of the farmers were within the ages to 30 to 60 years. This age group is usually believed to be the active age group. The result also showed that most (66.7\%) farmers were married. As regard the household size, it ranges from one to fourteen with the average size of the household of the farmers being six. These findings is closely supported by that of Oluwatosin (2011) who reported a mean household size of 7 and 8 people per household for yam farmers in Ondo state and Osun state respectively.

On the educational level of the farmers, $42.8 \%$ had no formal education, $25 \%$ had primary education, $22.8 \%$ had secondary education and $9.4 \%$ of the respondents had tertiary education. The years of farming experience ranges from 2years to 60years with an average of 25 years. $32.2 \%$ of the respondent had farming experience of 11 to 20 years, $20 \%$ had farming experience of 31 to 40 years, while, $16.7 \%$ had farming experience of less than 10 years. This shows the yam farmers had a significant level of expertise in yam production. This compares favourably with the findings of Oluwatosin (2011) that indicated a farming experience of 14 years for farmers in Osun state.

Table 2 Farmers Awareness Level of Yam Storage Technology (Y.S.T) in the Study Area

\begin{tabular}{llll}
\hline Y.S.T & Frequency $(\mathrm{N}=180)$ & Percentages & Rank \\
\hline Yam barn & 161 & 89.4 & $3^{\text {rd }}$ \\
Covered table & 143 & 79.4 & $5^{\text {th }}$ \\
Elevated pole & 145 & 80.6 & $4^{\text {th }}$ \\
Yam house & 169 & 93.9 & $2^{\text {nd }}$ \\
Heap on the floor & 170 & 94.4 & $1^{\text {st }}$ \\
Underground structure & 117 & 65.0 & $6^{\text {th }}$ \\
Open sided shelves & 80 & 44.4 & $8^{\text {th }}$ \\
Coating with termitarial soil & 93 & 51.7 & $7^{\text {th }}$ \\
Cold storage & 0 & 0 & $9^{\text {th }}$ \\
Gamma Radiation & 0 & 0 & $9^{\text {th }}$ \\
\hline
\end{tabular}

Source: Field survey, 2016 
The study shows that heap on the floor was the storage techniques that was popularly known to most of the farmers. This is followed by yam house and yam barn which ranked third in terms of level of awareness by the farmers in the study area. This finding is contrary to those of Suleiman (2014), Okoedo-Okojie and Onemolease (2009), whose studies revealed that yam barn ranked first, followed by heap on the floor.

It is worthy to note, however, that none of the farmers was aware of cold storage and Gama radiation storage techniques, which are modern and improved.

Table 3 Level of Usage of Yam Storage Techniques by Farmers in the Study Area

\begin{tabular}{|c|c|c|c|c|c|c|}
\hline Y.S.T & Often & Moderately & Seldom & $\begin{array}{l}\text { Weight } \\
\text { index }\end{array}$ & $\begin{array}{l}\text { Weight } \\
\text { average } \\
\text { index }\end{array}$ & Rank \\
\hline Yam barn & 143 & 13 & 3 & 458 & 2.54 & $1 \mathrm{st}$ \\
\hline $\begin{array}{l}\text { Covered table } \\
\text { (raised } \\
\text { platform) }\end{array}$ & 41 & 45 & 32 & 245 & 1.36 & $4^{\text {th }}$ \\
\hline $\begin{array}{l}\text { Elevated } \\
\text { horizontal } \\
\text { pole(tying on } \\
\text { tuber pole) }\end{array}$ & 22 & 42 & 45 & 195 & 1.08 & $5^{\text {th }}$ \\
\hline Yam house & 78 & 25 & 13 & 297 & 1.65 & $3^{\text {rd }}$ \\
\hline $\begin{array}{l}\text { Heap on the } \\
\text { floor }\end{array}$ & 122 & 22 & 13 & 423 & 2.35 & $2^{\text {nd }}$ \\
\hline $\begin{array}{l}\text { Underground } \\
\text { structure(pit, } \\
\text { ditches) }\end{array}$ & 34 & 26 & 23 & 177 & .98 & $6^{\text {th }}$ \\
\hline $\begin{array}{l}\text { Open sided } \\
\text { shelves }\end{array}$ & 12 & 30 & 11 & 107 & .594 & $8^{\text {th }}$ \\
\hline $\begin{array}{l}\text { Coating with } \\
\text { termitarial soil }\end{array}$ & 27 & 26 & 10 & 143 & .79 & $7^{\text {th }}$ \\
\hline
\end{tabular}

Table 3 indicates that storage of yam tubers in barns with the weight average index of 2.54 was the major storage method used by the respondents in the study area. This was followed 
by heap on the floor with the weight average index of 2.35. Open sided shelves were the least used storage techniques with 0.594 weight index score. This research tallies with the findings of Akangbe et al., (2012) who reported open sided store was the least used method by farmers in the storage of yam in Asa Local Government Area of Kwara State.

Factors Influencing Usage of Yam Storage Techniques by the Farmer

Table 4 Tobit regression result on the determinants of usage of yam storage techniques

\begin{tabular}{|c|c|c|c|}
\hline Variables & Coefficient & Standard Error & T-value \\
\hline Constant & 0.500267 & 0.050953 & 9.82 \\
\hline Household size & -0.00267 & 0.00556 & -0.48 \\
\hline $\begin{array}{l}\text { Highest education } \\
\text { level }\end{array}$ & 0.00936 & 0.01290 & 0.73 \\
\hline $\begin{array}{l}\text { Agricultural } \\
\text { association }\end{array}$ & -0.02239 & 0.03088 & -0.73 \\
\hline Access to credit & $-0.05699^{* *}$ & 0.02656 & -2.15 \\
\hline Crop yield & $0.000011^{* * *}$ & $3.22 \mathrm{e}-06$ & 3.54 \\
\hline Extension service & $0.097265^{\star *}$ & 0.032850 & 2.96 \\
\hline Farm size & 0.006500 & 0.010541 & 0.62 \\
\hline Farming experience & 0.001459 & 0.000987 & 1.48 \\
\hline \multicolumn{4}{|c|}{ Pseudo R2 = -0.4503, Log likelihood $=67.587429$, LR chi2 $(9)=41.97$, Prob $>$ chi2 $=0.0000$} \\
\hline \multicolumn{4}{|c|}{ Source: computer output } \\
\hline $\begin{array}{l}\text { The relatively small } \\
\text { explanatory variable. } \\
\text { variable jointly influer }\end{array}$ & $\begin{array}{l}\text { ue of the pse } \\
\text { e significance } \\
\text { usage of yam }\end{array}$ & $\begin{array}{l}\text { nay be due to } \\
\text { value of } 41.97 \\
\text { chniques. }\end{array}$ & $\begin{array}{l}\text { ement error in the } \\
\text { es that explanatory }\end{array}$ \\
\hline
\end{tabular}


The result in Table 4 shows that crop yield by the farmers was significant at $1 \%$ and had positive effect on the level of usage. This suggests that the higher the farmers yam yield, the higher the probability of usage improved storage techniques. This compares favourably with the findings of Omonona et al., 2006 who reported that crop yield significantly influence the usage of improved cassava varieties among rural farming households in Edo State. The study also shows that extension service was significant at $5 \%$ which implies that the more the farmers contact with extension agents the higher the probability of the farmers' using storage techniques. This is similar to the findings of Madukwe (1995), who reported that lack of sound technical knowledge arising from poor access to extension training impedes the usage of yam minisett technologies by small scale farmers in Southwestern Nigeria.

However, access to credit has a negative effect on the usage of yam storage techniques, which may suggest that as famers' access to credit increases, they tends to use the money for other activities. This could be attributed to the misuse of the credit facilities by the farmers. The findings of Jamilu et al., (2014) showed that some farmers use credit that is meant for production on consumption.

Effect of Yam Storage Techniques usage on Farm Income

Table 5 The effect of usage of yam storage techniques on farm income

\begin{tabular}{llll}
\hline & & Intensity & Farm income \\
\hline Intensity & Pearson correlation & 1 & $.179^{*}$ \\
& Sig. (2-tailed) & & .017 \\
Monthly income & $\mathrm{N}$ & 180 & 178 \\
& Pearson correlation & .179 & 1 \\
& Sig. (2-tailed) & .017 & \\
& $\mathrm{~N}$ & 178 & 178 \\
\hline
\end{tabular}

${ }^{*}$ Correlation is significant at the 0.05 level (2-tailed)

Table 5 shows that usage intensity has a positive effect on the farm income. This implies that the higher the level of yam storage technique used by the farmers, the higher the level of 
income of such farmers. This result compare favourably with the findings of Abdoulaye et al., 2014.

\section{CONCLUSION AND RECOMMENDATIONS}

Based on the findings of this study, it may be concluded that usage of modern yam techniques is low despite the losses due to the use of traditional techniques. Extension service and Crop yield significantly influence the level of usage of techniques. However, access to credit has a negative effect on usage of farm storage techniques. It is therefore recommended that extension agents should actively disseminate information on improved storage techniques to yam farmers in the study area as well as the need to use such techniques. New yam storage techniques should be made available to the farmers in the study area at subsidized rates so as to encourage them to use such techniques. Farmers should be trained on the usage of such modern storage techniques as cold storage, Gama radiation and other recent storage techniques that are not yet available in the study areas.

\section{REFERENCES}

Abdoulaye .T., Abass .A., maziya-Dixon B., Tarawali G., Alene A., Okechukwu R., Rusike J, and Manyong V. (2014): Awareness and adoption of improved cassava varieties and processing technologies in Nigeria. Journal of Development and Agricultural Economics. 6(2): 67-75 DOI: 10.5897/JDAE2013.006

Adisa R.S., Adefalu L.L., Olatinwo L.K., Balogun K.S., Ogunmadeko O.O. (2015): Determinants of postharvest losses of yam among yam farmers in Ekiti state, Nigeria. Bull. Inst. Trop. Agr., Kyushu univ. 38: 73-78

Akangbe, J.A., Oloruntoba, O. O., Ayanda, I.F. and Komolafe, S. E. (2012): An Analysis of Yam Storage Strategy to Promote Food Security. Ethiopian Journal of Environmental Studies and Management EJESM 5 (4): 550-558

Alimi H.M., Zango M.I. (2016): The Influence Of Socio-Economic Variables On Adoption Behaviour Towards Tadco Improved Rice Parboiling Technique Among Rice Parboilers In Kura Processing Areas Of Kano State, Nigeria. Agrosearch. 16 (2): 51-60

AMCOST (2006): Technologies to reduce post-harvest food loss. The African Ministerial Council on Science and Technology (AMCOST) of the African Union (AU), Pretoria, South Africa

Ekunwe and Osewa (2007): Technical efficiency and productivity of yam in Kogi state, Nigeria. Journal of applied science. 7 (13): 1818-1820 
F.A.O (2005): FAO Annual Report. Food and Agriculture Organisation Production Year Book. Food and Agricultural Organisation of the United Nations, Rome.

Jamilu, A.A., Abdul-Aziz, H., A. K. Jafaru., B. M. Sani and Abudu, S. (2014): Factors Influencing the Adoption of Sasakawa Global 2000Maize Production Technologies Journal of Agricultural Extension. 18 (1): 62-72

Madukwe M.C. (1995): Obstacles to Adoption of Yam Minisett technology by Small Scale Farmers of Southeastern Nigeria. Agrosearch. 1 (1): 1-6

National Population Commission (2006): Provisional National Censors report

Ndamani F.; Watanabe T. (2016): Determinants of farmers' adaptation to climate change: A micro level analysis in Ghana. Sci. agric. (Piracicaba, Braz). 73(3): 201-2018

Okigbo, R. N., \&Ogbonnaya, U. O. (2006): Antifungal effects of two tropical plant extracts (Ocimumgratissimum and Aframomummelegueta) on post-harvest yam rot. African Journal of Biotechnology. 5 (9): 727-731

Oko edo-Okojie .D. U. and Onemolease .E.A. (2009): Factors Affecting the Adoption of Yam Storage Technologies in the Northern Ecological Zone of Edo State, Nigeria. J Hum Ecol. 27(2): 155-160

Oladele O.I and Kareem A.I (2003) Adoption rate and continued use of selected arable crop technologies among farmers in Oyo State Nigeria. Food, Agriculture \& Environment. 1(3\&4): 291-294

Oluwatosin F.M. (2011): Measuring Technical Efficiency of Yam Farmers in Nigeria: A Stochastic Parametric Approach. Agricultural Journal 6 (2): 40-46.

Omonona B T, Oni O A and Uwagboe A O.(2006), "Adoption of Improved Cassava Varieties and its Welfare Impact on Rural Farming households in Edo State, Nigeria. Journal of Agricultural and Food Information. 7 (1): 35-39

Suleiman .M. (2014). Profitability ant technical efficiency of yam production in kiama local government area of Kwara state, Nigeria: A Bachelor of Agriculture project, Department of agricultural economics and farm management, university of Ilorin, llorin, Kwara state 